


\section{Individuals and Crowds. Presidential Leadership and Political Scenes of Representation in Media and Networks in Argentina (2008-2019)}

$$
\text { 产 }
$$

ARTICLE INFO:

Volume: 06

Issue: 02:2020

Month: March

ISSN: 2459-2943

DOl: 10.18680/hss.2020.0021

Pages: 57-83

Lic.: CC BY-NC-ND 4.0

KEYWORDS:

\author{
BY: Mariano Fernández and Gasón Cingolani
}

\section{ABSTRACT}

$\mathrm{T}$ his article offers a comparative analysis of the construction of political scenes of representation by two former Argentine presidents, Cristina Fernández de Kirchner (2008-2015) and Mauricio Macri (2015-2019), based on televised speeches and social media postings. As there is no political representation without staging, and any staging needs a material surface for its deployment, the comparative reconstruction of scenes of representation is required for understanding the impact of socio-technological transformations in the political field. Our analysis assumes that the political dramaturgy of representation entails: (a) that the leader must show a way of connecting with his constituents; (b) therefore, the leader must configure a preferred political subject (i.e., a predominant form of figurative citizenry); and (c) that this configuration constitutes a possible portion of the entire population that can be represented. According to our analysis, each leader is associated with a different type of representation scene. While one leader configures her scenes with large-scale crowds and via national television broadcasts, the other configures his encounters with individuals via social media. This engenders two opposing conceptions of citizenry, connectable to two different classes of Interpretants: a political-ideological Interpretant and an unpolitical and para-ideological one. 


\section{Introduction}

This article shall present a comparative semiotic analysis of two media strategies of political representation in Argentina. In employing a semiotic approach, we focus not on the institutional arrangements that ensure the functioning of the representative political system, but on the scenes of representation arranged by the last two presidents, Cristina Fernández de Kirchner (2008-2015, from now on, CFK) and Mauricio Macri (2015-2019, from now on, MM), instead. Paraphrasing Schmitt (2008), our study object is political representation considered as a 'symbolic figuration' and not as a 'mandate.' Unlike Schmitt, however, we do not think of representation as the figuration of a Being. In democratic systems, executive leaders must image the political bond that unites them with the represented. What needs to be represented is a type of relationship and not a singular entity. Thus, our analysis focuses on three different figurations: of the representative, of the represented, and of the type of bond forged between these two in the representation scenes.

What we call 'scenes of representation' is the analytical modeling of elements that belong to the contemporary media landscape, either as communication items or as products of political marketing: televised government events, social media postings, campaign ads, civic ceremonies. Since discursive figurations are objects inserted in the media communication flows, their analysis must focus on the political discourse mediatization conditions. Given these conditions, a semiotic of the political must also be a semiotic of politics' mediatization (Verón 1995).

With mediatization, we mean any message production or reception process involving media devices that decontextualize the spatial, temporal, and inter-subjective dimensions of established or novel cultural processes (Verón 2014; Cingolani 2014). Being both historical and analytical, this definition allows us to consider each historical and cultural context's specifics. Each period and culture is distinct, but different mediatization processes have operated since writing systems' appearance (Goody 1977). By mediatization of politics, then, we consider ways of producing politics on a scale that has been made possible by using the media. Mediatization's definition follows Veron's contributions $(2013,2014)$ but is also compatible with other contemporary conceptualizations, as well; like that of Krotz (2014), Couldry and Hepp (2013), Krotz and Hepp (2013), and Hepp (2020). ${ }^{1}$

Although based on a national case-study, the analysis proposed here goes beyond mere regionalism and allows us to tie together a series of problems affecting political discourse and political communication on a global scale. Firstly, the two presidential

\footnotetext{
${ }^{1}$ Thus defined, the concept of mediatization does not refer to a variation in the gradient of 'mediations' but to the political discourses' production conditions. We use the term 'mediation' to refer to institutional arrangements, regardless of whether they are mediatized.
} 
terms (2008-2019) correspond to the emergence and consolidation of Internet-based digital platforms (mainly Twitter, Facebook, and Instagram) as preferred scenes for political communication. In Argentina, this shift is replicated in the communication strategies of each president. As the leader of a political space that was part of Latin America's 'left turn' (Levitsky and Roberts 2011), CFK was a predominantly television figure. In contrast, $\mathrm{MM}$, as the political reference of the regional right that emerged as a reaction to the so-called 'Latin American populism' (Lupu 2016), chose social media as his primary public communication tool. Secondly, this correspondence, easily attributable to an epochal change in politics mediatization, took the form of an ideological dispute (Waisbord 2013; Kitzberger 2016), often framed in terms of populist versus democratic communication (Gallo 2019). Comparative analysis is a type of research that helps us understand how an ideological difference manifests simultaneously at the political discourse level and media communication. Thirdly, Argentina is not alien to the processes of "desacralization and relativization of the electoral function" that Rosanvallon (2008: 25) identifies as characteristic of contemporary democratic systems. One of these processes' effects is the difficulty of embodying figures of the social generality. Since Argentina has a presidential system, national elections shape political life, and consequently, the presidential figure is the significant center of the public sphere. The study of presidential representation scenes is, as a result, the privileged way to understand the dominant political imaginaries and conceptions of the citizenry.

In the following section, we explain the semiotic status of political representation as staging, not only as a theoretical principle but also as a constitutive empirical dimension of contemporary politics. Next, we proceed to outline the theoretical-methodological approach that informs the analysis presented in the subsequent sections. We conclude with a synthesis of our findings and a reflection on the debates we intend to contribute.

\section{Political Representation as a Semiotic Phenomenon}

Besides philosophical and sociological approaches, political representation is also perceived as a semiotic phenomenon. In the first place, it is so in an ontological sense, as Schmitt (2008: 243) stated: "Representation is not a normative event, a process, and a procedure. It is, rather, something existential. To represent means to make an invisible being visible and present through a publicly present one." This is also the case from the perspective of political theory, as Lefort rightly stated: "In a democracy, the concept of representation must also retain some of the meaning given to it by common language." That is, representation should not be understood only as a system in which representatives exercise political authority instead of citizens, but in the sense that "it 
guarantees visibility to society." In effect, to represent implicates "the creation of a political scene" (Lefort 2012: 21). Finally, the semiotic character of representation is also evident in its discursive dimension. As Saward suggests, there is "an indispensable aesthetic moment in political representation because the represented is never just given, unambiguous, transparent" (2006: 310). A representative has to be creative, has to "shape, and in one sense create that which is to be represented" (2006: 310).

This condition of staging political representation has also been identified with the category of 'political spectacle' (Edelman 1988) or with the notion of 'video-politics,' which implies a "radical transformation in our way of being politicians" (Sartori 1998). Both these views propose that contemporary news media and especially television had a drastic impact on the relations between rulers and citizens, effectively altering the arché of politics. With regards to its essential functions, however, we can say that political representation adapts to the changing communication media (Debray 1995: 66). The electronic media in the second half of the 20th century and the Internet at the turn of the millennium have transformed how State and government produce political spectacles rather than the fundamental semiotic ontology of political representation (Veron 1989a: 82). The State - and, by logical implication, the body of rulers as well - has always been spectacular (Debray 1995: 60; Balandier 1994: 25). On a macro-scale, "there is no State without spectacle"; instead, "it is the spectacle that makes the State" (Debray 1995: 62). And on a micro-scale (based on the everyday experience of citizens in their relationship with the political system), television produced "a re-appropriation of the most archaic level of meaning." Thus, the political began to signify the immediate territory, to play out in the micro-exchange, forcing the "decoding of the signifying body" (Verón 1989a: 82). Social media have further intensified this phenomenon. The ecology of platforms (van Dijk 2013; Fernández 2018) has brought about vital innovations in political mediatization and media discourse circulation (Van Aelst et al. 2017; Bennett and Pfetsch 2018). However, from the interface's point of view (the point where production and reception get interconnected), social media, just like mass media, are immense showcases for political scenes of representation.

Either way, nobody could deny that the scenes in which political leaders display their representative status have become part of our daily media consumption and a vital segment of political communication strategies. This plethoric new political imaginary demands to rethink the future of our societies, and in particular what Manin, a quarter of a century ago, described as 'audience democracy.' For Manin, this notion identified the consolidation of a new form of representative democracy, a metamorphosis of the so-called 'party democracy' (Manin 1995: 185-186). The figure of the 'audience' was not a pejorative expression of the supposedly passive behavior of the electorate but a metaphor used to describe the new operating conditions of political representation. These conditions include the following two crucial factors: First, a shift 
in "the personal nature of the representative relationship," particularly evident in countries where the head of the executive branch is directly elected and national elections shape political life. Secondly, Manin noted that "voting behavior varies according to the terms of the electoral choice: Voters seem to respond (to each election's particular terms), rather than just express (their social or cultural identities). [...] Today, the reactive dimension of voting predominates" (Manin 1995: 192).

Beyond the macro-social factors of these transformations, Manin offered two complementary principles of analysis that are still applicable. Firstly, "the channels of political communication affect the nature of the representative relationship" (Manin 1995: 193). Secondly, as exogenous demand does not exist in politics, the analogy between electoral choice and the market-place is problematic. Thus, argues Manin, the metaphor of stage and audience is a more satisfactory, even if imperfect, to represent this reality (1995: 193).

Although many things have changed in the last quarter of a century, Manin's analysis remains valid. On the one hand, we are undergoing a structural change in politics' mediatization conditions, with the center of gravity shifting from television to digital platforms. On the other hand, despite disrupting the political system's institutional mediations, these changes reaffirm both the metaphorical and empirical significance of the 'stage' figure as a central component of democratic representation. For this reason, we believe that the present article converges towards Manin's analysis from the 1990s. In the end, we propose the study of those scenarios in which the political representation is configured, not as 'metaphors' but rather as material objects in which governors unfold, in front of the citizenry, their representative status in the public space.

\section{Methodology}

Our analysis will mostly focus on the audiovisual language of the representation scenes rather than their linguistic dimension. The representative-represented bond's figuration articulates the audiovisual with the linguistic (we will refer to speech fragments when necessary). Other essential political discourse operations (like the triple destination), based on language, will not be discussed here.

Our research corpus comprises two sets with different characteristics. On the one hand, we studied a series of 30 televised events held by CFK between 2008 and 2015. These events' character is diverse, including national celebrations, official announcements, collective mobilizations in support of the Government, and party conferences. In all cases, televising was mostly conducted through the National Radio and the TV Broadcasting Network — called Cadena Nacional. In Argentina, it is a presidential prerogative that enables the interruption of the leading radio and television network broad- 
casting to put live government speeches on the air. This practice was highly effective for reaching the general population in the era of few media; currently, the media offer is so abundant that the effect of this interruption is not as pragmatic as it is political. To simplify our exposition, we have selected photos of these acts to illustrate the distinctive features of CFK's performance scenes.

On the other hand, we have studied 60 posts on Instagram and Twitter made by MM between 2015 and 2019. The selection was made manually, through screenshots. Although most of these posts consist of a photograph accompanied by a short text, the corpus also included some videos taken from the official YouTube channel managed by the Presidential Residence (Casa Rosada).

At first glance, the composition of both sets of data appears to hinder their comparison. However, the unity of semiotic analysis cannot come from the properties of the analyzed texts themselves, since these always manifest a multiplicity of restriction systems (Verón 2004 [1975]: 72). The comparison can only stand based on criteria outside discourse, set in two levels: a) in relation to text selection criteria; b) in relation to the reading purpose (Verón 2004 [1975]: 72).

Regarding the first point, it is noteworthy that both presidents used various forms of political communication. Though reluctant to interact with the media and the journalists, CFK gave some interviews and used her Twitter and Facebook accounts. For his part, despite having focused his political communication mainly on social media (especially Facebook and Instagram), MM also held televised events and gave interviews and press conferences. However, our corpus' composition reflects their main media preferences, a criterion based on practical knowledge of the matter and analyses carried out by other scholars (Annunziata et al. 2018; Cingolani 2012; Gindin 2019; Montero 2018; Slimovich 2017).

The heterogeneity of the two sets of the corpus is one of our analysis objects. We wish to compare two predominantly audiovisual representation scenes. Mass media exposure of presidential discourse (as in CFK's case), involving a mostly photographic strategy that induces a lateral circulation; and social media-based everyday communicative spaces that operate independently from media agendas (as in MM's case).

Concerning the second point (the reading purpose), we have built our work upon a definition of the notion of the scene of representation that facilitates the operational reduction of the multiplicity of its constituent elements (Rivière 1989: 157). The notion of the scene is neither an allegory nor a metaphor but a material configuration whose semiotic composition is necessarily heterogeneous and irreducible to linguistic materiality. In this sense, a political representation scene comprises of:

i. a semiotic spatial-temporal configuration, composed of an assembly of topographies, bodies, and objects in which a strategy of making sense is deployed, including its mediatization; 
ii. in this scene, an individual - an expression, itself, of a force or a set of social and political forces - is constructed as a representative,

iii. from the staging of a bond with other individuals or groups, either present or evoked, with whom he or she maintains a leadership relationship;

iv. therefore, he or she must configure a preferred political subject (i.e., a predominant form of figurative citizenry); and

v. that configuration constitutes a possible portion of the whole representable population;

vi. consequently, the recurrence or stabilization of that configuration results in an Interpretant as a conception of the citizenry.

Three aspects of this definition require further clarification. Firstly, to classify and describe the variations of representation scenes, we have used the concept of 'regime of visibility' proposed by Landowski (1985). This concept allows us to analyze the actants' modalization based on the intersection of individual/collective and public/private conceptual pairs. The latter, according to Landowski, follows "a common principle, relative to the admission or exclusion of a witness instance ('them')," modifying the nature in the actants' figuration. At the level of private individuality, ' $\mathrm{I}$ ' is ' $\mathrm{I}$ ' [je] in relation to a 'you' [vous]. But gathered in the same space, 'we' [nous] is defined in relation to 'they,' which is not necessarily an adversary, an identity border. Thus, a 'we' can be outlined as a 'public collective' (for example, in the celebration of a civic ceremony) and a 'we' configuring a 'private collective' (for example, party meetings broadcast on television).

Secondly, any staging of a representation of collectives requires a figuration of these represented collectives. ${ }^{2}$ As an operation of meaning, Traversa defines figuration (1997: 251) as "the modes of semiotization of an identifiable entity," and then as "a result: a construction and, as such, the effect of intersecting operations: more precisely, chains of operations, which are situated at different levels of text organization." The analysis of figuration enables us to identify the representational operation of the collective figure staged and understand an essential part of the staging strategy.

The third aspect derives precisely from the place that the 'witness instance' occupies in defining the scenes of representation when these are mediatized (whether they are televised or posted on social media). There are two juxtaposed issues here. On

\footnotetext{
${ }^{2}$ The notion of figuration does not strictly refer to the theatrical metaphor of staging but the condition of the semiotic construction of a representation. Thus conceived, figuration is a way of construction resulting from a set of operations. Theoretical perspectives as disparate as those of Parret (1993), Latour (2005: 53-62), and Hepp (2020) have applied this notion, taken from Greimasian semiotics, to the sociology of networks or media theory. Despite their differences, all focus on its non-representational, constructivist character. We adopt Traversa's definition because it systematizes a methodology of rhetorical and operational analysis for this construction from a semiotic perspective.
} 
the one hand, every scene of representation is, by definition, public (Schmitt 2008: 242). Therefore, it addresses an audience, that is, a heterogeneous collective. Clearly, it does not address the whole population indiscriminately. On the contrary, it "proposes a modeling of social identities" (Veron 1989b: 139). A reception study could reveal the sociodemographic or sociological composition of this collective. But for semiotic analysis, these scenes are defined by their condition of signs; that is to say, they are there for an Interpretant (Peirce 1998). Taken as a "collectivization operator" (Genard 2017: 3), the Interpretant's notion offers an appropriate analytical solution to reconstruct which strategy the representation scenes are configuring in their recurrence and regularity.

In pluralistic democracies, every political discourse, finally, by engaging in a field of struggle and competition, is inserted in a "triple destination device" (Veron 1987, García Negroni 1988). It addresses, at the same time, supporters, opponents, and the undecided or independent. No political discourse produces a single effect. Therefore, our notion of Interpretant refers to a production strategy that entails a specific way of interpreting this triple destination. Of course, this does not mean that reception can be pre-determined or that there is only one way of interpreting a discourse. Its 'correct' interpretation implies political adherence. An Interpreter comprises the set of systematizable regularities and variations of a discursive strategy sustained over time.

\section{Scenes of Presidential Political Representation: Figures of Leadership and Figuration of Citizenry}

\subsection{CFK: From the Ceremonial Mobilization to the Partisan Ceremony. The Ritual Meeting with the Crowd}

CFK served as president for two consecutive terms (2007-2011 and 2011-2015). Upon winning her first election, she already was a political figure of public importance and had a long career as a parliamentarian, but she was not strictly speaking a leader. The role of a reference authority of a political force was occupied, at the time, by her husband and former president, Néstor Kirchner. By contrast, when her second term ended, CFK was (and still is) the most important political figure in recent history in Argentina.

Throughout her eight years of government, CFK produced four major performance scenes, summarized below (Table 1). We should consider each modality as a sort of general type, which includes potential variations. As explained in the methodological section, to simplify the operational description, we have used the concept of 'visibility regimes.' Each scene of representation is inserted into a different regime of visibility, and each regime expresses a variation in the figuration of the representative relationship. 


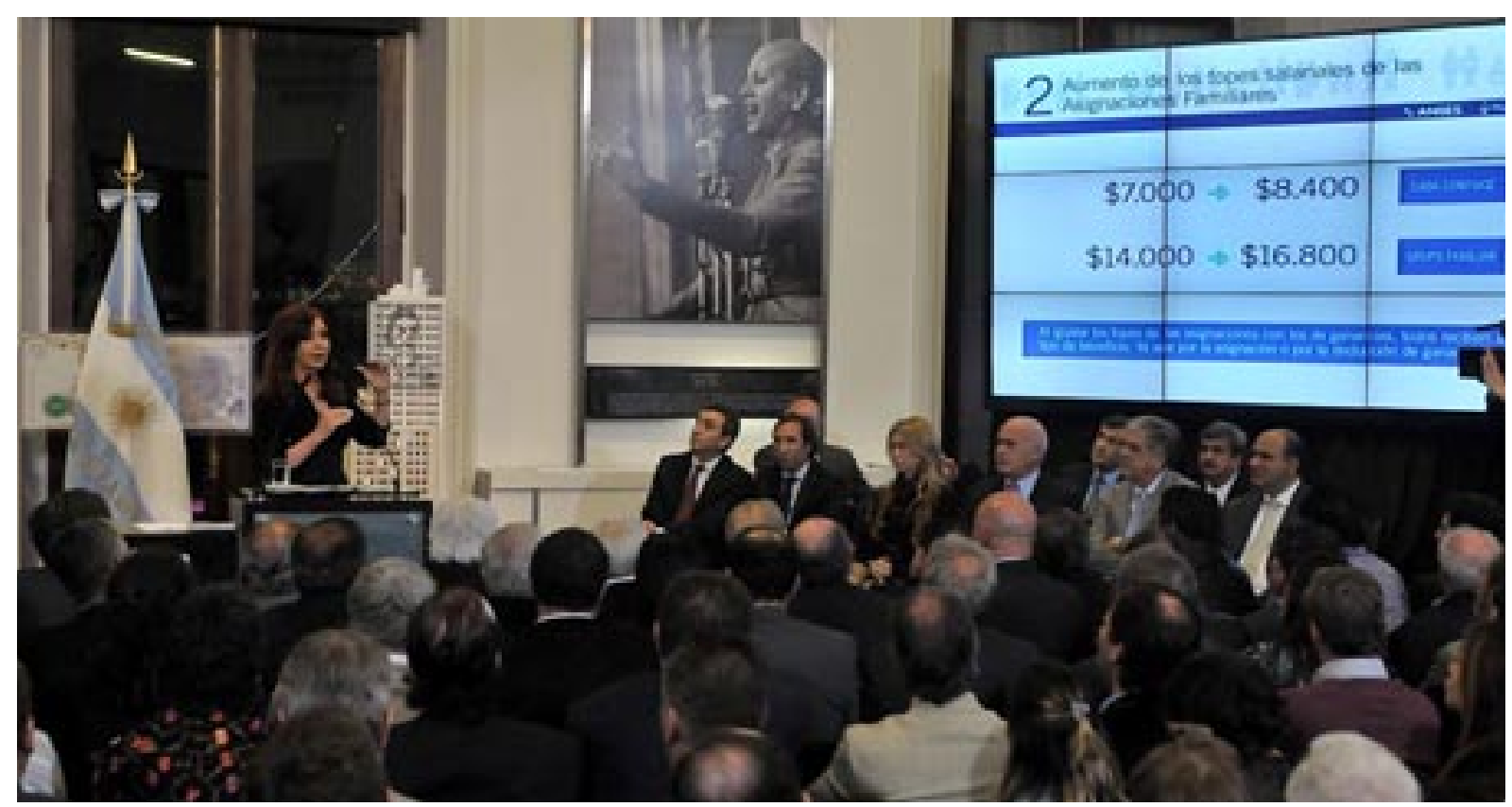

To draw up this classification, we shall follow the analysis proposed by Dayan and Katz in their classic study on media events (1992). Events staged expressly for an audience, which, as Landowski notes, necessarily transforms their nature as semiotic objects. Dayan and Katz (based on Lang and Lang) developed a typology that distinguishes events according to their function as 'unifiers' or 'polemics' (1992: $42-43$ and 127-128). What emerges is a combined classification producing four types of events, ${ }^{3}$ which we have adapted to our study object. We have already noted that CFK's staged scenes were televised events. This implies that there is a common denominator beyond the internal variations between each scene type. Each of them offers the image of an encounter of a representative with their constituents and appears to the media audience, absent as a direct interlocutor but present as a bystander.

\section{a. Esoteric Monologue}

This regime of visibility is characteristic of events such as the inauguration of public works, presentation of bills, launching of state programs. The figure of the national leader is staged here in a way that places it above sectoral interests. In the first place, this status is marked by a scenography privileging the visibility of patriotic symbols (flags, portraits of national heroes). It is further amplified by the presence of popularly elected political representatives (governors, mayors, legislators) and federal cabinet ministers standing next to or behind CFK but always sharing the stage with her. In front of her, on the other hand, the audience is composed of sectoral representatives (union leaders,

\footnotetext{
${ }^{3}$ Ceremony (unifying/audience as a witness); Spectacle (unifying/audience is required); Esoteric Debate (controversy / audience as a witness); Adversary Proceeding (controversy/audience is needed) (Dayan and Katz 1992: 243n).
} 
leaders of social organizations, human rights organizations, businessmen, bankers, sometimes prominent cultural figures). From the logic of the topographical distribution of places (further forward, further back) and from how CFK herself directs her gaze (she never looks at the camera), it can be said that a sort of closed circuit is formed. This produces two effects. Firstly, the president does not address the television audience directly. Thus, as a generic target, the citizenry is relegated to the witness's role in a dialogue that does not include them directly. Secondly, the composition of the audience does not follow an ecumenical criterion. Those who are present are sympathizers of the Government; their presence indicates endorsement. Since the camera usually captures the viewers' faces using individual shots, it is not difficult for a viewer with an average lateral knowledge (Barthes 1980) of national political life to notice this ideological composition.

\section{b. Exoteric Ceremony}

This scene of representation is characteristic of civic festivities. The ceremonial feature derives from their commemorative function (e.g., the independence revolution). Civic festivities are what Abélès (1989) calls 'rites of consensus,' events that mark the community's symbolic continuity. As such, they are events organized by the State. The President is present in his / her capacity as head of the executive, as a supra-partisan figure. On the other hand, the exoteric feature stems from the fact that these are scenes that unfold in some urban space, open to public participation. The predominance of national

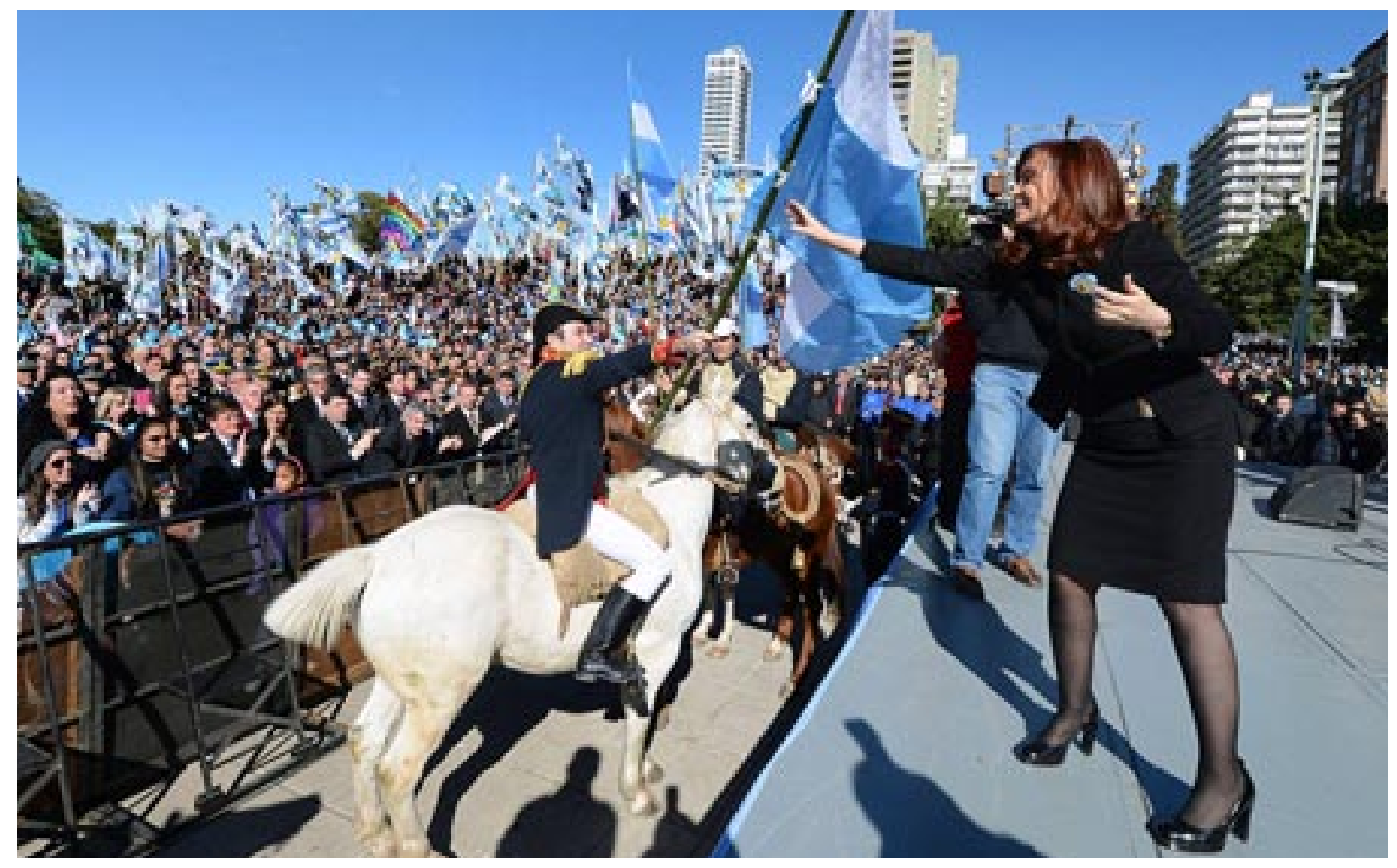


flags shows that those present identify themselves as citizens of the national community and not as political rights subjects. This condition of individuals melted into a collective festivity gathered in the celebration of shared history is also reinforced by the CFK herself when giving speeches. For example, at the celebration of the independence revolution in Plaza de Mayo square on May 25, 2014, CFK told the crowd:

Do you Argentines realize that we gathered here today to celebrate May 25, the national day, and the nation's recovery for all Argentines? It seems silly, but it is not foolish; it is a reaffirmation of belonging and cultural identity.

\section{c. Charismatic Ceremonial Mobilization}

This scene is a variation between the 'exoteric ceremonies' and the regime of visibility that we call 'partisan ceremony' (see next section). This type of scene became increasingly common in the last years of CFK's second presidency due to the establishment of her leadership. From the perspective of the visibility regime's composition, there is almost no variation from the ceremonies we have already described but in the representation bond's figuration. That is because, in charismatic ceremonial mobilizations, the meeting of the collective is explained not only as a celebration of the community (as in the rites of consensus) but also as a meeting of a militant crowd with its leader. Even if the general framework continues to be that of civic festivities, what occurs is an overlap between the Homeland celebration as an entity transcending any particularism and the self-celebration of a political collective's uniqueness. This tension expresses itself at a

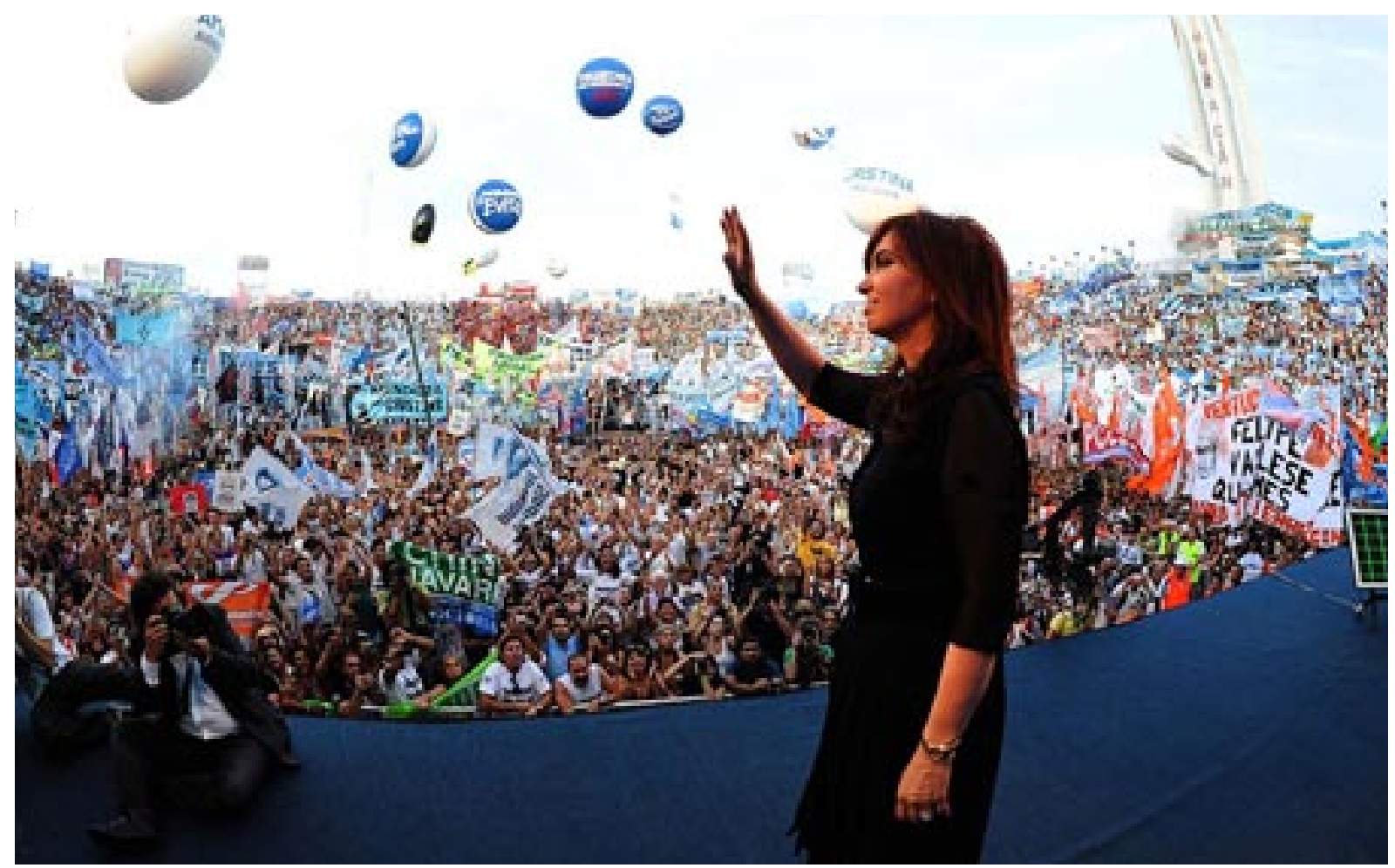


semiotic level. Unlike what happens in exoteric ceremonies, the crowd is a marked collective, whose features facilitate the "operation of symbolic reading" (Schaeffer 1990: 34): carrying party flags and banners of various government-related social organizations, singing songs vindicating the figure of CFK. In short, a group gathered in a square to celebrate the Homeland and listen to its leader. In the mix between generic multitudes ('the Argentines') and militant collectives, the figure of CFK appears no longer as a national leader but as one of a plebiscitary type, reinforced and updated by this cross-party meeting.

\section{d. Partisan Ceremony}

This is the regime of visibility that defined the uniqueness of political representation in CFK and against which, as we shall see, MM's political representation was built. The function of the partisan ceremonies is the revitalization of a political collective of identification, a clearly defined 'we.' In this sense, it is an instance of the exaltation of what Landowski calls "private collective" (1985: 4). Considered from the logic of political representation, however, in these scenes leadership is put into action and reproduced as the capacity to lead a partisan political force. No matter their scale, history, and electoral weight, all organized political groups need this type of self-celebrating event. What makes a difference in the case of CFK is that these scenes became televised political liturgies.

As liturgies (Rivière 1989), they were not an electoral tool, but dramatic incarnations of leadership and political identity. They were regular and ritualized practices with a stable morphology (Rivière 1989: 180). They could only be sustained over time because the existence of the collective participating as the protagonist transcends the moments of celebration. In the case of CFK, her political leadership cannot be understood outside the political movement that supported her, known as 'Kirchnerism' (Retamozo and Trujillo 2019). This denomination was, in principle, a way of designating the followers of former president Néstor Kirchner in the 2003-2007 period of government, but, with time, it became a political identity that not only described a center-left tendency within Peronism but also took from it its movementist character (Pérez and Natalucci 2014). Made up of non-partisan political actors (such as social organizations) and non-Peronist political parties, it was also characterized by a return to a deep-rooted tradition in Argentina: regular collective mobilization as a sign of support for its political leader.

Unlike ceremonial mobilizations, whose occurrence follows the civic calendar, partisan ceremonies have their temporal inscription, according to each political force's founding dates and milestones. Also, in this case, they were usually used as a tactical resource, such as demonstrations of strength and support for CFK in times of political 


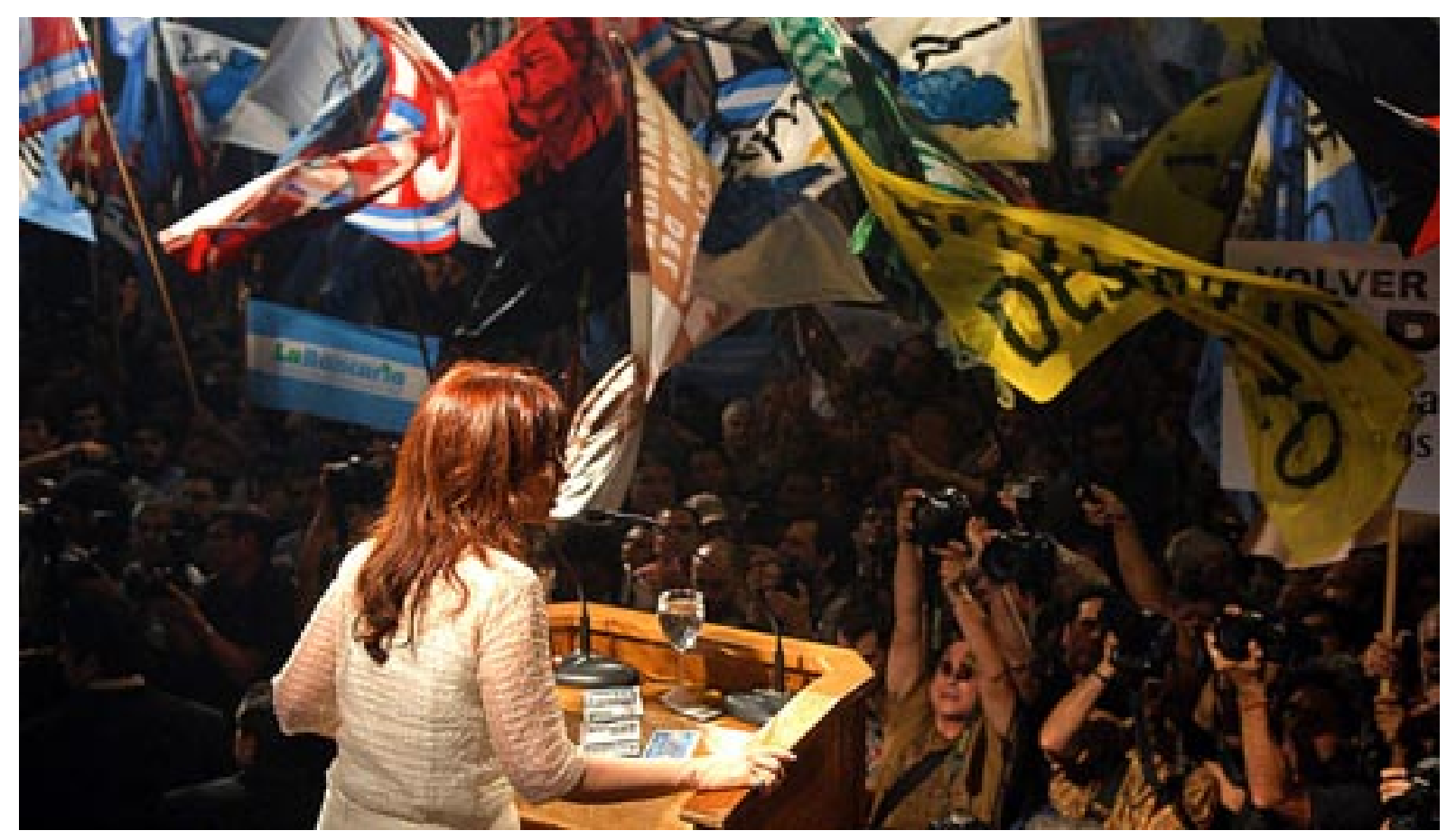

crisis. In turn, while ceremonial mobilizations are framed by state rituals' institutional rules, partisan ceremonies are para-institutional acts, carried out in closed places, or at least restricted with respect to urban topography (usually football stadiums).

These scenes involve a dialogue, whose structure is not, however, symmetrical. On the one hand, there is a crowd mobilized to listen to CFK. This listening is not passive; the collective gathering plays an acting role (Greimas 1966; Barthes, 1966): the multitude jumps, sings, underlines some passages of the speech with ovations or applause. The audiovisual discourse (which is, as it should be noted, under the control of the governing party itself rather than private television stations), synchronized and attuned to the dramatic fluctuations of the presidential talk, reinforces the dynamics of the scene. On the other hand, the scene has a center, which is the body of CFK. Not surprisingly, the shot that best expresses this dynamic is the low-angle panoramic shot from the speaker's back.

Thus, the relationship between CFK and these multitudes is an identity structured by a mutually complementary relationship (Bateson 1972; Veron 1995), bonding the leader with her followers. It is precisely within this bond that the figure of each one of them is defined, a bond which has been reinforced by the CFK herself: "My dear fellows: as president, but mainly as a militant, I would like to thank all of you for this true celebration of joy, happiness, and nationality" (27/04/2012).

However, it is not enough to point out that the collective gathered there is a collective of identification (Veron 1987). Throughout her two terms, CFK pursued a close political alliance with the youngest segments of organized militancy. This alliance be- 
came especially evident in her second government's composition, provoking an internal dispute with other Peronist party's sectors (Rocca Rivarola 2017). The president often emphasized this alliance in her speeches: "I feel that you are the true guardians of this legacy, and you are not going to allow a step back in all that we have achieved" (27/04/2013).

Some of these meetings were identified with a specific name, 'The Militant Courtyards.' That is how the meetings held between CFK and the Kirchnerist youth were called. These events usually took place after televised public events (often framed within the visibility regime understood as an esoteric monologue). Once the event was over, the crowd entered the Government House's interior courtyards, where the meeting with CFK took place, this time under the regime of the partisan ceremony (see image below).

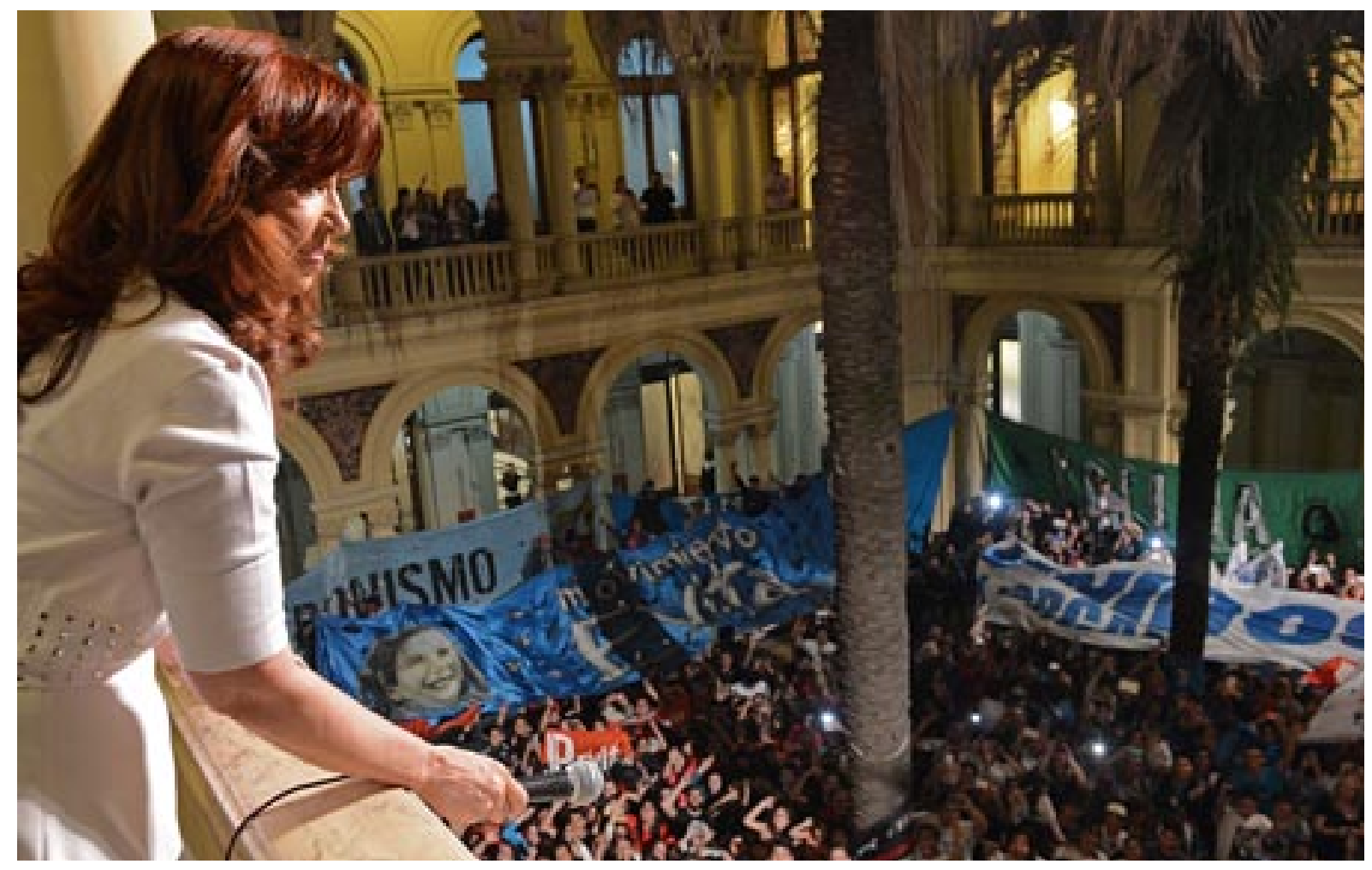

The broadcast of these events merits two observations. On the one hand, their stature as political liturgies overlaps with their importance as media events included in the flow of newsworthy items making up the media agenda. On the other hand, being televised introduces a crucial element in the reconstruction of their Interpretant. As it happens in ceremonial mobilizations, media audiences act as a 'witness instance': not as guests but as necessary participants for that event in which they get involved as spectators. 
As we have seen in ceremonial mobilizations, another tension emerges here as well. Rivière (1989: 123) explains that every ritual has a triangular structure. Its constitutive elements are the organizers, the actors, and the spectators. But when the liturgy is broadcasted, this tripartite structure undergoes a significant change, especially the place of the spectator, which is doubled: this liturgy becomes a spectacle that can be consumed live potentially by the whole of society (even by those who may not share the beliefs that mobilize this ceremony). But what kind of spectacle is offered to the television audience? If an Object's semiotic status is defined by the Sign/Interpretant relationship, in this case, the composition of the scene invites an identification not with a figure or a collective but with the type of bond established. So what kind of bond is configured in these scenes? It is a bond based on a presupposed and shared belief, a type of belief that allows any identification collective to be sustained over time. In one of these liturgies, CFK said: "Those who are on television and want to listen to the President should turn off the television because they are only going to listen to a Peronist militant" (14/09/2010). Perfect tension between the Interpretant presupposed by the presidential institution - the citizen as an individual endowed with rights and responsibilities and the collective that CFK built as a privileged recipient of her speeches: the militant as a subject engaged in a political project.

Table 1.

\begin{tabular}{l|l|l|l}
$\begin{array}{l}\text { REGIME OF } \\
\text { VISIBILITY }\end{array}$ & $\begin{array}{l}\text { TYPE } \\
\text { OF EVENT }\end{array}$ & $\begin{array}{l}\text { FIGURATION OF } \\
\text { THE REPRESENTED }\end{array}$ & $\begin{array}{l}\text { FIGURATION OF THE } \\
\text { REPRESENTATIVE }\end{array}$ \\
\hline Esoteric Monologue & $\begin{array}{l}\text { Protocolar } \\
\text { Work Opening } \\
\text { Announcement }\end{array}$ & $\begin{array}{l}\text { Citizens (as formal } \\
\text { status defined by the } \\
\text { National Constitution) }\end{array}$ & $\begin{array}{l}\text { National Leader } \\
\text { (complementary) }\end{array}$ \\
\hline Exoteric Ceremony & $\begin{array}{l}\text { Commemorative } \\
\text { Inserted in the media } \\
\text { agenda }\end{array}$ & $\begin{array}{l}\text { Citizens } \\
\text { (as a belonging embo- } \\
\text { died in values, affects } \\
\text { and traditions) }\end{array}$ & $\begin{array}{l}\text { National Leader } \\
\text { (complementary, } \\
\text { charismatic) }\end{array}$ \\
\hline $\begin{array}{l}\text { Charismatic } \\
\text { Mobilization }\end{array}$ & $\begin{array}{l}\text { Citizenry } \\
\text { mobilization } \\
\text { supporting the } \\
\text { President }\end{array}$ & $\begin{array}{l}\text { Citizens (as an active } \\
\text { political practice) }+ \\
\text { supporters }\end{array}$ & $\begin{array}{l}\text { Plebiscitary Leader } \\
\text { (complementary, } \\
\text { charismatic) }\end{array}$ \\
\hline Partisan Ceremony & Partisan Mobilization & $\begin{array}{l}\text { Supporters } \\
\text { (defined by ideological } \\
\text { belonging) }\end{array}$ & Party Leader \\
\hline
\end{tabular}




\subsection{Mauricio Macri's Scenes of Representation: From the Rite of the Personal Meeting and the Minimalist Anti-ceremony to the Anti-partisan Ceremony}

An outsider to Argentine political parties tradition, MM won the presidency in 2015 as the Cambiemos right-wing liberal alliance candidate. Trained as a businessman, he served for eight years as mayor of the country's wealthiest district, the City of Buenos Aires, leading a neighborhood party. Since his election campaign, he has produced a mediatized direct contact strategy with citizens by making door-to-door visits (a practice known as 'doorbelling'). Photo and short video postings on social media complemented this strategy. Similarly, he used this strategy when meeting entrepreneurs, traders, etc. The figuration of representation was not only different from CFK's but directly opposed to it. While CFK relied on state-owned television, MM opted for a robust presence on social media platforms (Slimovich 2020). He maintained this strategy for most of his government's term until nearly the end of 2019.

\section{a. The Rite of the Personal Meeting}

The figuration of the face-to-face encounter was MM's founding matrix. It entails the portrayal of a meeting with a neighbor or some citizens in an ordinary, everyday locale: at the front door, a cafe, or a corner store. In all these scenes, it is MM who goes in search of the citizen. Photographic records of these meetings were not produced according to the pose's regime but rather as situational snapshots, as if the protagonists of the encounter were not observed but inadvertently captured (Barthes 1980; Verón 1994). The shots are taken at eye level, producing a homology with the 'human' scale of the situation and favoring a naturalistic interpretation of the scene: those houses, those sidewalks, those cafes have local details, they show what is not prepared to be captured.

Also, these scenes do not contain any conflict, and they are not narrative. In general, individuals are smiling calmly, conversational gestures reflecting an informal, nonfunctional type of exchange. On occasion, the relationship appears modalized by an attitude of listening, indulgence, or redemption (a hand on the shoulder, a hug) on the part of MM towards the neighbors, or with an 'interiority' gaze, that is, not focused on something external and visible, nor oriented towards some specific action but projecting an attitude of mutual attention.

These characteristics are present both in photographs and videos. In the videos, this naturalism is reinforced by their often vertical orientation (portrait mode), shaky camera technique, and poor sound quality, aiming to give the impression of a spontaneous shoot made with a smartphone. The dialogues (voice in) are typically not audible. When we can discern some fragmentary sounds, they consist of phatic or emotive signals (Jakobson 1963) like greetings or salutations, without reference to some specific 
issue or state of affairs. The represented relationship with the citizenry is (audio)visually diegetized, encapsulated in a situation where the spectator's vision (and hearing) is entirely external to that of the persons involved. In campaign spots, besides, looking at the camera is avoided. These static and silent scenes entirely resist a visual-only mediatization, even with a single still image, as they comprise situations without before or after. They are encounters that do not occupy time and place on the social agenda and could have happened at any time, anywhere, and with anyone.

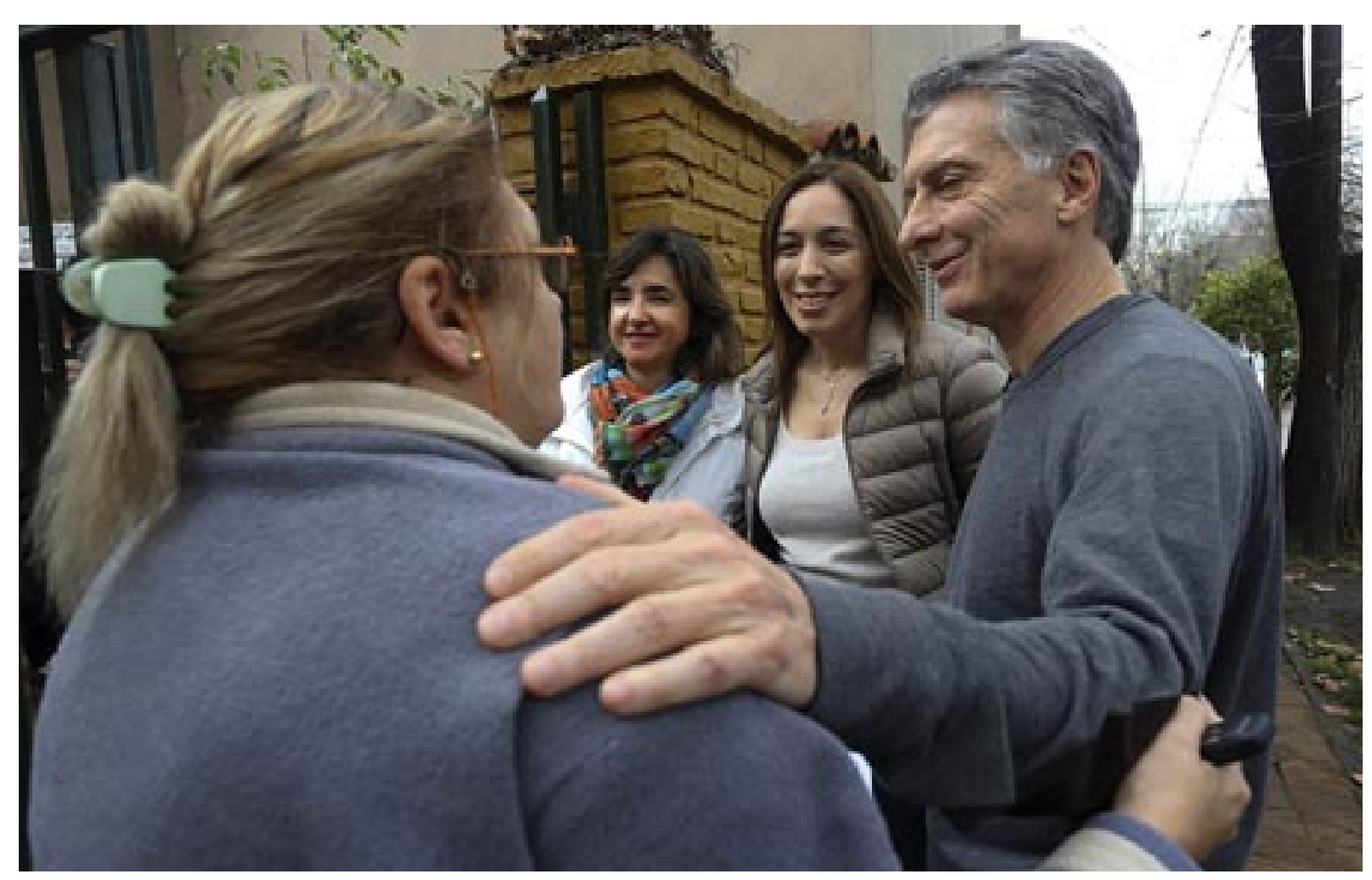

The organization of individuals' subtractive attributes in $\mathrm{MM}^{\prime}$ 's strategies has an evident semiotic relevance. This operation aims to configure the opposition between militants and citizens, the latter incarnated as an unmarked figure, as the zero degree of the non-ideological (Barthes 2002). This dichotomy is enshrined in Cambiemos' contention (echoing the neoliberal discourse) that party militancy goes against citizens' liberal aspirations, patriotism is an obstacle to individual fulfillment (Souroujon 2019), and politics is a defrauding practice that involves only costs and no benefits.

Contrary to what happens with CFK acts (in which individuals are involved explicitly as participants in a collective body), individuals serve as the support of the representative-represented bond. The analysis must take into account the fact that these are two completely different figurations of individuality. In MM meetings, some neighbors are called by their first name ('Johana,' 'Lucas,' 'Alicia and Marcelo'), and a geographical reference is given ('Jujuy,' 'La Matanza'). Of course, an individual body is 
visible, with a face and a specific location (the front door or a house yard, a repair store, a corner store, a cafe). Despite the existential uniqueness, these elements are recognizable by the general public but not identifiable.

The distinction between recognition and identification in the interpretation of an iconic-indexical text such as a photograph, as proposed by Schaeffer (1990: 67-80), can be very useful in this case. Photographic image recipients can recognize a type of entity (a man, a house, a boulevard). Still, they cannot identify its uniqueness (Uncle Robert, my grandmother's house, the park where we used to play). Very close to MM, men, women, even children can be seen smiling or even hugging him. Their identification, however, is not provided by the image (except the scarce case of knowing these people beforehand) but by the accompanying caption: 'Juan from Quilmes.' That would be enough to go from absolute iconic-indexical indeterminacy to relative indeterminacy (Schaeffer 1990: 80), based on recognizing that these people can exist and the caption allowing identification is presumed true. But even so, it does not reach the full saturation of the identification. Therefore, each figurative person becomes a representative of a type (social, geographical): they constitute a generic character.

The social attributes of CFK followers are not random or undifferentiated, but, ultimately, they also generate types. In contrast, however, to MM's neighbors, CFK followers are marked: they manifest their adherence and participation in the political movement with their body (individual and collective). In MM's strategy, individuals are also identifiable by social segment, but: a) they are stripped of attributes of militancy, b) instead of being mobilized, they are visited or approached by MM, and c) they do not configure a collective entity, just a generalization: 'Juan from Quilmes' is someonelike-others who are not figurative but (and therefore) represented. However, following the semiotic imperative of analyzing the image in its pragmatic logic (Schaeffer 1990), that is, considering the relationship between the Interpretant and the Representamen, these images require not an individualizing but a stereotypical identification: an individual is 'similar' to so many others, he/she belongs to the 'common citizen' type (Annunziata 2013), which for Macrism is defined, first and foremost, by not being a militant. This bundle of attributes figures profiles, not singularities. Moreover, this profiling is organized mainly by subtraction: what they do not have, what they do not do, what they are only as a potentiality.

\section{b. Minimalist Anti-ceremony}

In inauguration parties, public events, ceremonies, or protocol announcements, the mediatized staging of a government can take three forms: show, direct appealing, or intermediation (Cingolani and Fernández 2019). The differentiating features are based above all on two articulated operations: the presence of an audience on the scene -the 
speaker's body recipient (to whom the speaker directs his/her gaze)-, or its absence, corresponding to a look at the camera (Landowski 1985).

Throughout his political career, MM has avoided speaking to crowds. While in office as mayor of the City of Buenos Aires but also later, during his presidential term, he was increasingly adding audiovisual broadcasts of public events (inauguration parties, ceremonies, speeches) set in a minimalist rhetoric, with short and not very solemn speeches, stripped of large stages and crowds, and in locales not been traditionally used for political events. The events were held in front of small groups and avoided the prominence of these groups. The field of view cut by the cameras was located at eye level between the speaker and the audience, leaving the latter out of the visual and sound field or incorporated only as a counter field. The contrast with CFK and the Argentine political tradition is quite strong: once the complementarity is deactivated, it offers a relationship of representation without differences of scale, a flat figuration of contact, and the least possible resemblance to what might seem (usually) political. The bodies then appeared on the same level, even symmetrically (Bateson 1972; Verón 1995). The operation consisted of showing closeness and even reversibility. For example, while MM gave his speech, he was often accompanied by people who were not public officials or an audience in itself. If the event was related to some public work or factory, he was escorted by workers wearing helmets or uniforms. Also, if the act pertained to public transport, MM could be found standing next to a few passengers on a bus; if it took place in a school, he would appear seated at a desk like a pupil among children. And whenever possible, his body assumed some of the attributes of the citizens in their situational roles.

As in the ritual personal visit strategy, individuals figure as decorations of the situation, acting as extras, as figurant (Didi-Huberman 2014). In visual arts history, the figurant could be represented schematically: a silhouette, a vaguely shaped figure, suggesting a soldier, a monk, a longshoreman, etc. As a result of the iconic-indexical nature of the photographic or videographic images, the figurant was redefined. If the portrait produces identification by qualitative features (physiognomic, emotional, emblematic) and certifies the existence of the portrayed (Todorov 2004), the extras are only identifiable as a stereotyped form: he or she is $a$ worker, $a$ teacher, $a$ neighbor.

But there is a second quality that produces the figurant - a quality that does not depend on the figuration's material condition: the lack of actantiality in the story (Greimas 1966; Barthes 1966). As a result of this lack, those who appear as neighbors in MM's social media images (Cicowiez 2019), as citizens in the personal encounter strategy, and as a worker, a passenger, or a student in the minimalist anti-ceremonies, become figurants as well. In a way, this deprives the character of a place in History, such as the 'little man,' Ricoeur's le prochain ([1954) 1967). If the People are a collective, an actant in its History, it is not surprising to find it missing in MM's strategies (Mazzuchino 2017). The category neighbor or citizen does not point to an individual or a group: it constructs a type. 
To understand this operation, we can turn to Peirce (1906), who formulated the difference between individual and type, ad their possible interactions. In classifying signs according to their Representamen, he argues that the singular sign (Sinsingn) can refer to an individual or collection of individuals while the conventional sign (Legisign, ' $a$ law that is a sign') is that which can represent a type. Due to the hierarchies principle, the Legisign needs 'replicas' or tokens (Sinsigns) to work, but not vice versa. The neighbor or citizen as a type is a generalization, even if a singular event or entity represents it. Since a full identification of the individual cannot be produced (Schaeffer 1990: 6780 ), it is not because of its singularity that it creates meaning. The only thing that remains is its recognition, that is to say, its generic interpretation. The individual figure is, consequently, predominant in both the personal encounter and the minimalist anti-ceremony strategies. However, due to its ritual character, individuals' figuration in both strategies always and necessarily refers to a type. And especially of an unmarked kind, such as a zero degree of the plural figure, valid as a citizen or neighbor (personal meeting rite) or as a worker or entrepreneur (minimalist anti-ceremony) without partisan or 'interested' marks.

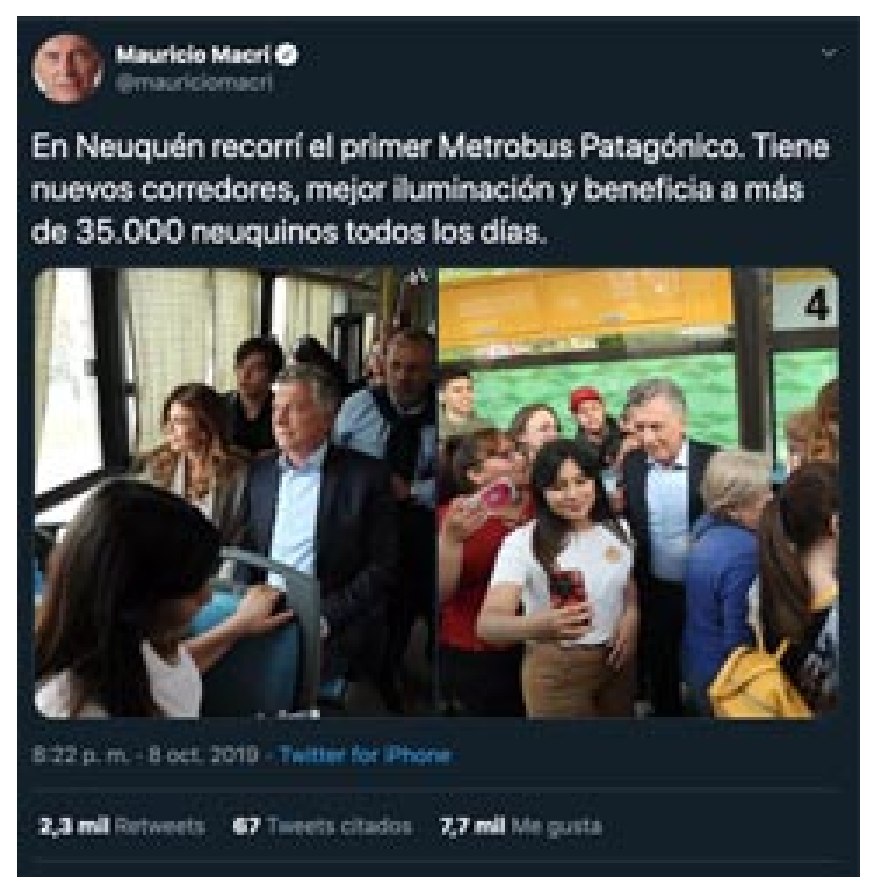

\section{c. Non-partisan \& Non- governmental Mobilization (Anti-partisan Ceremony)}

In the last stage of MM's presidency, a change in strategy is noticeable in his reelection campaign (in 2019): the adoption of mass actions and, in general, of more traditional forms of political mobilization in Argentina. The '\# 24A' (August 24), the 'March of the Million' (October 19), and the 'Farewell' (December 7) were actions exhibiting several of the qualities that MM had till then avoided, disqualified and in opposition to which he had forged his political and media identity. What stands out in these acts is the figuration of those represented as a crowd. To differentiate themselves, MM insisted on avoiding partisan symbols and using only national emblems. This third strategy is clearly opposed to the previous ones in three aspects: the figuration of a collective body (the crowd appears), the mobilizing nature (it is the individuals who go to meet MM and not the other way around), and the figuration of individuality as the support for the expression of claims and demands; they 


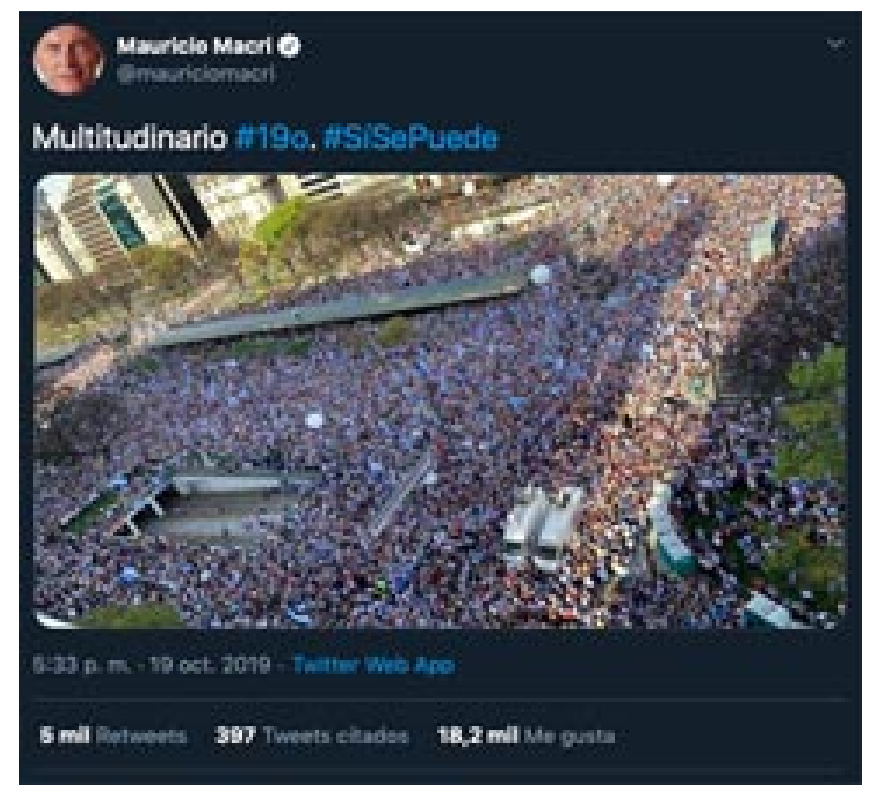

are bodies with a voice. This implies a shift in the Interpretant of the representation relationship. But the adoption of symbols and slogans identified with the Nation (Argentine flags) and the Republic (banners with demands for the independence of institutions, text fragments from the National Constitution) constitutes a synthesis between the rejection of party adherence and the electoral agenda of a party while in office.

Table $2 .^{4}$

\begin{tabular}{l|l|l||l}
\hline $\begin{array}{l}\text { REGIME OF } \\
\text { VISIBILITY }\end{array}$ & $\begin{array}{l}\text { TYPE } \\
\text { OF EVENT }\end{array}$ & $\begin{array}{l}\text { FIGURATION OF } \\
\text { THE REPRESENTED }\end{array}$ & $\begin{array}{l}\text { FIGURATION OF THE } \\
\text { REPRESENTATIVE }\end{array}$ \\
\hline $\begin{array}{l}\text { The Rite of the } \\
\text { Personal Meeting }\end{array}$ & $\begin{array}{l}\text { Out of the agenda } \\
\text { event, quasi-private }\end{array}$ & $\begin{array}{l}\text { Non-mobilizated } \\
\text { citizens: individuals- } \\
\text { type (neighbours) }\end{array}$ & $\begin{array}{l}\text { Proximity Leader } \\
\text { (symmetrizing, anti- } \\
\text { charismatic) }\end{array}$ \\
\hline $\begin{array}{l}\text { Minimalist } \\
\text { Anti-ceremony }\end{array}$ & $\begin{array}{l}\text { Public governance } \\
\text { milestone, ceremonial } \\
\text { celebration, quasi- } \\
\text { public }\end{array}$ & $\begin{array}{l}\text { Sub-mobilizated } \\
\text { citizens: individuals- } \\
\text { type (workers, city in- } \\
\text { habitants) }\end{array}$ & $\begin{array}{l}\text { Proximity Leader } \\
\text { (symmetrizing } \\
\text { government agent) }\end{array}$ \\
\hline $\begin{array}{l}\text { Non-partisan \& } \\
\text { Non-governmental } \\
\text { Mobilization (Anti- } \\
\text { partisan Ceremony) }\end{array}$ & $\begin{array}{l}\text { Anti-partisan } \\
\text { mobilization }\end{array}$ & $\begin{array}{l}\text { Mobilizated citizens: } \\
\text { Non- auto-identified } \\
\text { as partisans sup- } \\
\text { porters Collectives }\end{array}$ & $\begin{array}{l}\text { Plebiscitary Leader } \\
\text { (un-polítical, para- } \\
\text { ideological) }\end{array}$ \\
\hline
\end{tabular}

\section{Summary and Conclusions}

We can summarise our findings from the comparative analysis of the CFK and MM representation scenes as follows:

i. The series of CFK scenes we analyzed typically concerns a leader's encounter with collective bodies that vary according to the political conjuncture. Regularities and

\footnotetext{
${ }^{4}$ In the representation scenes classification, we have retaken CFK's types of events and created categories based on their contrast.
} 
variations reveal themselves spatially (uses of public space) and temporally (inserted in an agenda of general impact), in the context of a mediatization approach based on live television broadcasting. The MM series of scenes, on the other hand, typically involves the leader meeting individuals or small groups. However, the latter are recognizable by the citizenry mainly as types, with no significant territorial specificity, since the identity of locations is too general. Simultaneously, they have little temporal specificity since meetings are no part of the official agenda, do not involve organized collectivities or communities but few individuals, or take place laterally through social media. These MM strategies demonstrate a multi-local and focal mediatization plan, based on circulation in social media rather than in broadcasting media.

ii. CFK alternately takes on the role of national leader, party leader, or plebiscitary leader, while MM stands solely as a citizen leader.

iii. While CFK always projects a complementary bond with the collective body, MM seeks to project a symmetrical, horizontal bond with it.

iv. The groups called upon to be represented by CFK vary between citizens constituted by law, citizens as members of a Nation, militants, and the People/plebs; on the other hand, MM invokes non-mobilized citizens (neighbors) and undermobilized citizens (work, trading, city dwellers). In the last year of his government, his strategy appealed to groups interested in general public affairs but had no appeal to party organizations.

v. Considered globally -including their variations- both strategies seem not only to differ in content (which we do not explore here) but also in how they stage representation. The portioning of collectives by CFK entails their participation in the collective mobilization, the leader's legitimacy founded on that participation. For its part, MM's strategy focuses on individuality, the leader's legitimacy founded on his targetted attention to citizens.

vi. The two strategies for the configuration of scenes of political representation entail conflicting Interpretants about the citizenry; namely, they suggest conflicting models of participation in res publica and taking an interest in community matters. The fundamental Interpretant of CFK's political representation scenes is a conception of the citizenry that shall be referred to as political-ideological. With this label, we delineate a way of conceiving the citizen as a political subject with an ideologically framed understanding of the political order, assembling the world's singular events in an ordered and coherent narrative. It is a maximalist conception of citizenry, whose prototypical figure is the militant. On the contrary, the Interpretant of MM's political representation scenes is a 'depoliticized' conception of citizenry (Barthes 2002: 104-105) that can be called unpolitical and para-ideological. 
According to Rosanvallon (2008: 22), unpolitical describes a failure to develop a 'comprehensive understanding of problems associated with the organization of a shared world.' It is a minimalist and aggregative conception of citizenry, whereby the citizen is an individual who interprets the political-social world from the perspective of his / her private sphere or his / her immediate life environment, without inscribing that vision within a global framework (in this sense it is para-ideological).

In this sense, the Interpretant's semiotic notion becomes highly relevant; it lends itself to be set apart from both the collective of representation and the destination. The Interpretant here embodies the staging strategy as a whole, encompassing the various types of groups configured in each particular staging.

\section{ACKNOWLEDGMENTS}

We would like to thank the anonymous reviewers for their comments and suggestions, as well as our Argentinean colleague Irene Gindin for her accurate reading of the first version of this article. Their remarks have significantly improved our work.

\section{References}

Abélès, Marc 1989. Rituals et communication politique moderne. Hermès 4: 127-141.

Annunziata, Rocío 2013. La figura del 'hombre común' en el marco de la legitimidad de proximidad: ¿un nuevo sujeto político? Astrolabio 10: 127-155.

Annunziata, Rocío, Andrea Fernanda Ariza and Valeria Romina March 2018. 'Gobernar es estar cerca.' Las estrategias de proximidad en el uso de las redes sociales de Mauricio Macri y María Eugenia Vidal. Revista Mexicana de Opinión Pública 13(24): 71-93. DOI 10.22201 / fcpys.24484911e.2018.24.61520

Balandier, George 1994. El poder en escenas. De la representación del poder al poder de la representación. Barcelona: Paidós.

Barthes, Roland 1966. Introduction à l'analyse structurale des récits. Communications 8: $1-27$.

Barthes, Roland 1980. La Chambre Claire : Note sur la photographie. Paris: Gallimard.

Barthes, Roland 2002. Le neutre. Cours et séminaires au Collège de France 1977-1978. Paris: Seuil/Imec. 
Bateson, Gregory 1972. Steps to an Ecology of Mind. New York: Chandler Publ. Co.

Bennett, Lance, and Barbara Pfetsch 2018. Rethinking Political Communication in a

Time of Disrupted Public Spheres. Journal of Communication 68(2): 243-253 https: / / doi.org/10.1093/ joc/jqx017

Cicowiez, Mariano (2019). El candidato y la vecindad. La campaña de Cambiemos 2015. UNLP. Tesis. https: / / doi.org/10.35537/10915/66776

Cingolani, Gastón 2012. A midiatização da figura presidencial: espaços, estratégias e transições. In: Fausto Neto, Antônio, Jean Mouchon and Eliseo Verón (eds.) Transformações da midiatização presidencial. Corpos, relatos, negociações, resistências. São Caetano do Sul: Difusão Editora, 53-67.

Cingolani, Gastón 2014. ¿Qué se transforma cuando hay mediatización? In: Rovetto, Florencia and María Cecilia Reviglio (eds.) Estado actual de las investigaciones sobre mediatizaciones, CIM, UNR Editora: Rosario, 11-23. https: / / bit.ly/37fh3aP

Cingolani, Gastón and Mariano Fernández 2019. Cristina, un espectáculo político. Cuerpos, colectivos y relatos en la última presidencia televisiva. Buenos Aires: Prometeo.

Couldry, Nick and Andreas Hepp 2013. Conceptualizing Mediatization: Contexts, Traditions, Arguments. Communication Theory 23: 191-202. DOI: 10.1111 / comt.12019

Dayan, Daniel and Elihu Katz 1995. La historia en directo. La retransmisión televisiva de los acontecimientos. Barcelona: Gustavo Gili.

Debray, Régis 1995. El Estado Seductor. Las revoluciones mediológicas del poder. Buenos Aires: Manantial.

Didi-Huberman, Georges 2014. Pueblos expuestos, pueblos figurantes. Buenos Aires: Manantial.

Edelman, Murray 1988. Constructing the political spectacle. University of Chicago Press. Fernández, José Luis 2018. Plataformas Mediáticas. Elementos de análisis y diseño de nuevas experiencias. Buenos Aires: Crujía Futuribles.

Gallo, Julián 2019. Sobre el video de Mauricio Macri en la casa de una familia. Infobae, April 19. Available from: https: / / bit.ly / 3aiWjkk [Accessed: May 5, 2019]

García Negroni, María Marta 1988. La destinación en el discurso político: una categoría múltiple. Lenguaje en contexto I (1/2): 85-111.

Genard, Jean-Louis 2017. La consistance des êtres collectifs. Contribuer avec Peirce à une sociologie de l'engagement. SociologieS, Special Issue: La consistance des êtres collectifs. Mode(s) d'existence, dilemmes ontologiques et politiques. Available from: https: / / bit.ly/3dd464Z

Gindin, Irene Lis 2019. ¡Animémonos a imaginarlo! Análisis del discurso presidencial de Mauricio Macri. In: Iglesias, Esteban y Juan B. Lucca (eds.) La Argentina de Cambiemos. Rosario: UNR Editora, 43-59.

Goody, Jack 1977. The Domestication of the Savage Mind. Cambridge: Cambridge University Press. 
Greimas, Algirdas J. 1966. Réflexions sur les modèles actantiels. In: Sémantique structurale. Recherche de méthode. París: Larousse, 172-189.

Hepp, Andreas 2020. Deep Mediatization. Key Ideas in Media and Cultural Studies. New York: Routledge.

Jakobson, Roman 1963. Linguistique et poétique. In: Essais de linguistique générale. Trans. Nicolas Ruwet. Paris: Minuit, 213-222.

Kitzberger, Philip 2016. Media Wars and the New Left: governability and Media Democratisation in Argentina and Brazil. Journal of Latin American Studies 48: 447-476. https: / / doi.org/10.1017/S0022216X15001509

Krotz, Friedrich 2014. Mediatization as a mover in modernity. In Knut Lundby (ed.) Mediatization of communication. Berlin, New York: de Gruyter, 131-161.

Krotz, Friedrich and Andreas Hepp 2013. A concretization of mediatization: How mediatization works and why 'mediatized worlds' are a helpful concept for empirical mediatization research. Empedocles. European Journal for the Philosophy of Communication 3 (2), pp. 119-134. DOI: 10.1386/ ejpc.3.2.137_1

Landowski, Eric 1985. Eux, nous et moi: régimes de visibilité. Mots 10: 9-16.

Latour, Bruno 2005. Reassembling the Social. An Introduction to Actor-Network-Theory. New York: Oxford University Press.

Lefort, Claude 2012. Democracia y representación. Buenos Aires: Prometeo.

Levitsky, Steven and Kenneth M. Roberts 2011. Latin America's 'left turn.' A framework for analysis. In: Steven Levitsky and Kenneth M. Roberts (eds.) The resurgence of the Latin American Left. Baltimore: Johns Hopkins University Press, 1-28.

Lupu, Noam 2016. Latin America's New Turbulence: The End of the Kirchner Era. Journal of Democracy 27(2): 35-49.

Manin, Bernard 1995. Principes du gouvernement représentatif. Paris: Calmann-Lévy.

Mazzuchino, María Gabriela 2017. Twitter como espacio (¿anti?)político: análisis discursivo de los tuits del presidente Mauricio Macri. Revista Latinoamericana de Estudios del Discurso 17(2): 65-82. DOI: 10.35956/v.17.n2.2017.p.65-82

Montero, Ana Soledad 2018. Gestionar la duda. La interpelación al paradestinatario en el discurso de Cambiemos. Revista Mexicana de Opinión Pública 13(25): 41-61. DOI 10.22201/ fcpys.24484911e.2018.25.61706. Available from https: / / bit.ly / 3jUHk38

Parret, Herman 1993. The Aesthetics of Communication. Pragmatics and Beyond. The Haye: Springer.

Peirce, Charles Sanders [1903] 1998. Nomenclature and Division of Triadic Relations, as far as they are determined. In: Houser, Nathan and Christian Kloesel (eds) The Essential Peirce. Volume 2: Selected Philosophical Writings (1893-1913), 289-299.

Peirce, Charles Sanders 1906. Prolegomena for an Apology to Pragmaticism. The Monist 16: 492-546 (CP 4571 ss.). Available from: https: / / bit.ly/3piuJYJ 
Pérez, Germán and Ana Natalucci 2010. La matriz movimentista de acción colectiva en Argentina. La experiencia del espacio militante kirchnerista. América Latina Hoy 54: 97-112.

Retamozo, Martín and Lucía Trujillo 2019. The Kirchnerism and its political strategies in Argentina: From 'transversality' to 'Citizen Unity'. Izquierdas 45:185-214.

Rivière, Claude 1989. As liturgias políticas. Río de Janeiro: Imago.

Ricoeur, Paul [1954] 1967. Le socius et le prochain. In: Histoire et vérité. Paris: Seuil, 113127.

Rocca Rivarola, María Dolores 2017. La militancia kirchnerista. Tres momentos del compromiso activo oficialista (2003-2015). In: Pucciarelli, Alfredo et al. (eds.) Los años del kirchnerismo. La disputa hegemónica tras la crisis del orden neoliberal. Buenos Aires: Siglo XXI, 319 - 347.

Rosanvallon, Pierre 2008. Counter-Democracy. Politics in an age of distrust. New York: Cambridge University Press.

Sartori, Giovanni 1998. Homo videns. La sociedad teledirigida. México: Taurus.

Saward, Michael 2006. The Representative claim. Contemporary Political Theory 5(3): 297318. DOI: https: / / doi.org/10.1057 / palgrave.cpt.9300234

Schaeffer, Jean-Marie 1990. La imagen precaria (del dispositivo fotográfico). Madrid: Cátedra.

Schmitt, Carl 2008 [1928]. Constitutional Theory. London: Duke University Press.

Slimovich, Ana 2017. La ruta digital a la presidencia argentina. Un análisis político e hipermediático de los discursos de Mauricio Macri en las redes sociales. Dixit 26: 24-43. Available from: https:/ / bit.ly/3jNg32C

Slimovich, Ana 2020. Instagram y política. Mediatización y circulación en los perfiles de Cristina Fernández de Kirchner y Mauricio Macri. Cuaderno 112: 177-203. Available from: https: / / bit.ly/3rUN5AU

Souroujon, Gastón 2019. El Macrismo: cuando la honestidad reemplazó al patriotismo. In: Iglesias, Esteban y Juan B. Lucca (eds.) La Argentina de Cambiemos. Rosario: UNR Editora, 23-42.

Todorov, Tzvetan 2004. Eloge de l'individu. Essai sur la peinture flamande de la Renaissance. Paris: Seuil.

Traversa, Oscar 1997. Cuerpos de papel. Figuraciones del cuerpo en la prensa. 1918-1940. Barcelona: Gedisa.

Van Aelst, Peter, Jesper Strömbäck, et al. 2017. Political communication in a high-choice media environment: a challenge for democracy?. Annals of the International Communication Association, 41(1): 3-27. DOI: 10.1080/23808985.2017.1288551

van Dijck, Jose 2013. Culture of Connectivity: A Critical History of Social Media. Oxford: Oxford University Press. 
Verón, Eliseo 2004 [1975]. Ideología y comunicación de masas: sobre la constitución del discurso burgués en la prensa semanal. In: Eliseo Verón, Fragmentos de un tejido. Barcelona: Gedisa, 71-109.

Verón, Eliseo 1987. La palabra adversativa. Observaciones sobre la enunciación política. In: Eliseo Verón, Leonor Arfuch, et al. El discurso político. Lenguajes y acontecimientos. Buenos Aires: Hachette, 11- 26.

Verón, Eliseo 1989a. Télévision et démocratie: à propos du statut de la mise en scène. Mots 20: 75-90.

Verón, Eliseo 1989b. Semiótica y teoría de la democracia. Revista de Occidente 92: 130142.

Verón, Eliseo 1994. De la sémiologie de l'image aux discursivités. Le temps d'une photo. Hermès 13/14: 45-64.

Verón, Eliseo 1995. Médiatisation du politique: stratégies, acteurs et construction des collectifs. Hermès 17-18: 201-214. DOI: 10.4267/2042 / 15217

Verón, Eliseo 2013. La semiosis social, 2. Ideas, Momentos, Interpretantes. Buenos Aires: Paidós.

Verón, Eliseo 2014. Mediatization theory: a semio-anthropological perspective and some of its consequences. In: Knut Lundby (ed.) Mediatization of Communication. Berlin/Boston: De Gruyter Mouton, 163-172.

Waisbord, Silvio 2013. Vox Populista. Buenos Aires: Gedisa.

\section{AUTHOR}

Mariano Fernández Professor in Communication and Media Semiotics, National University of La Plata (UNLP) and the National University of the Arts (UNA), Buenos Aires, Argentina.

\section{AUTHOR}

Gastón Cingolani Director of the Institute for Research and Experimentation in Art and Criticism (IIEAC) at the National University of Arts (UNA), Buenos Aires, Argentina. Professor in Communication and Media Semiotics at UNA and National University of La Plata (UNLP). 


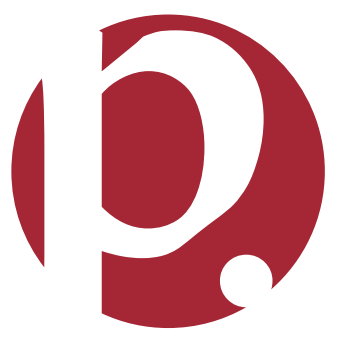

